UDC 623.1/.7:007.52 (477)

\title{
INFLUENCE OF AIR SHOCK WAVE ON BUILDINGS AND STRUCTURES
}

\author{
M.O. Shyshanov ${ }^{1}$, \\ Doctor of Technical Science, Professor \\ V.G. Maliuha ${ }^{2}$, \\ Doctor of Technical Sciences, Researcher \\ V.V. Koval ${ }^{3}$, \\ Candidate of military science, Senior Researcher \\ V.I. Mirnenko ${ }^{4}$, \\ Doctor of Technical Science, Professor \\ V.M. Fil ${ }^{4}$, \\ Candidate of Technical Science, Associate Professor \\ S.O. Hannenko ${ }^{4}$, \\ R.V. Duzhyi ${ }^{4}$ \\ ${ }^{1}$ Central research institute of weapons and military equipment of the Armed Forces of Ukraine, \\ 28, Povitroflotskiy avenu, Kyiv, Ukraine \\ ${ }^{2}$ Kharkiv National University of the Air Force. Ivan Kozhedub, Kharkiv \\ ${ }^{3}$ Military Scientific Department of the General Staff of the Armed Forces of Ukraine \\ ${ }^{4}$ Nationa Defense University of Ukraine named after Ivan Chernyakhovsky, 28, Povitroflotskiy \\ avenu, Kyiv, Ukraine
}

DOI: $10.32347 / 2410-2547.2020 .105 .179-191$

The destruction of buildings and structures takes place as a result of calamities, accidents of various nature, and terrorist attacks which often include explosions. In armed conflicts, the destruction of buildings and constructions happens as a result of munitions completely penetrating structural floors or walls, after which the round explodes inside the construction, followed by the destructive impact of explosion product kinetic energy and the shock wave.

The impact of shock wave on buildings and constructions is characterized by complex pressure: excessive pressure, reflective pressure, dynamic pressure, flowing pressure, seismic wave pressure.

Ensuring the preservation and restoration of buildings and structures includes measures to assess the possible degree of destruction of buildings and structures. Therefore, in modern conditions, the design of buildings, structures and their elements is not possible without taking into account the dynamic effects. When designing and constructing buildings and structures, it is always necessary to take into account the resistance of structural elements to the action of damaging factors, both the explosion in general and the shock wave of the explosion in particular, which will help avoid future possible human losses.

Considering the aforementioned, this article describes the basic characteristics of the air shock wave and building interaction processes, the panel construction rupture time calculation method, and the general characteristics of an explosion's air shock wave that penetrates buildings, constructions that have doors, windows, and openings which appeared due to damage to flooring or wall structures.

(C) Shyshanov M.O., Maliuha V.G., Koval V.V., Mirnenko V.I., Fil V.M., Hannenko S.O., Duzhyi R.V. 
Studies show that structural loads depend on the characteristics of the wave that penetrates through openings in constructions and through openings created by wall damage; while comparing calculations with experiment data shows a decent level of similarity between them.

Key words: air shock wave, dynamic load, reflection pressure, breach pressure, developed pressure, cover pressure, rupture time.

Introduction. The current climate change on Earth is followed by techno genic and natural calamities, while international relations are bare terrorist attacks and armed conflicts. Consequently, the need arises to study emerging threats and to predict possible building/construction rupture in order to apply preventive measures that reduce possible material losses and save human lives $[1,2]$.

Natural disasters, accidents, modern weapon employment often result in explosions. Depending on the type and yield strength of an explosion, as well as distance, design and size of elements of a building, explosion orientation, location of buildings and constructions, the impact of an air shock wave is going to vary. Thus, data characterizing explosions is needed in order to enable decision making on air shock wave protection for buildings and constructions, as well as to ensure explosion protection measures.

The most reliable information about the explosion can be obtained by conducting an experiment. However, this approach cannot always be applied. For that reason the most common calculation methods to determine the values of the parameters that characterize the explosions.

The aforementioned requires a more in-depth study of explosion process result impact and resilience of buildings and constructions calculation.

Analysis of research and publications has shown [1-7] that the study of the impact of the explosion on buildings and structures is given sufficient attention. At the same time, the issues of the impact of the shock wave on the structural elements of buildings and structures need additional study in order to solve the current scientific and practical problem of determining ways to improve the protective properties of reinforced concrete, concrete and brick structural elements of buildings and structures.

An air shock wave is a zone of strong air compression that propagates in all directions from the center of the explosion at high speed [ $8-11]$. The defeat is primarily caused by the occurrence of high excess pressure, which almost instantly compresses the human body or other object, causing damage and destruction. Along with this, the impact causes high-speed pressure, having a strong metallic ability. In addition to the direct impact of the shock wave, damage can be caused by fragments of elements of buildings, structures or other objects.

Considering everything mentioned above, the purpose of this article will be to determine the parameters of the shock wave of the explosion penetrating the building, structure and the parameters of the dynamic loads on their structures.

The main material of the article. The pressure on the internal structures of buildings depend on the parameters of the wave that flows through the 
openings and holes that are formed during the destruction of the walls of the building $[3,9]$.

The frontal wall is initially affected by the pressure of reflection $\Delta P_{v i d}$, at the edges of the wall and its holes there are waves of rarefaction, the outspread of which leads to a decrease in pressure on the structure over time $t_{o b t}$ to the value of the flow pressure $\Delta P_{o b t}$ (Fig. 1).

The time $t_{o b t}$, during which the pressure at the frontal obstacle decreases to the flow pressure is taken depending on the smaller of the two values $S=h$ or $B / 2$ by the formula (1)

$$
t_{o b t}=\frac{3 S}{D_{F}},
$$

where $h$ - is a distance from the the ground to the window or the height of the building (when the front wall without windows); $\mathrm{B}-$ is the width of the building.

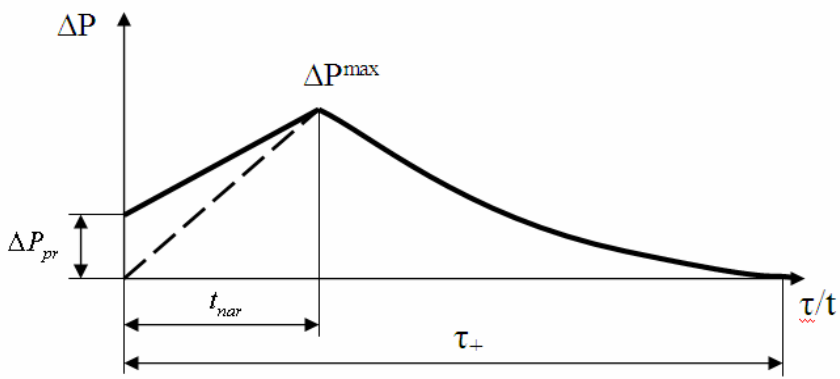

Fig. 1. Estimated pressure graph in the middle of a building with window openings. The dotted line shows the change in pressure inside the room with a smaller capacity $10 \%$

At the same time, the shock wave outspread through holes in the walls of the building. Assume that the measurement of pressure over time inside the building has the form shown in Figure 1.

The leakage pressure $\Delta P_{p r}$ corresponds to the excess pressure at the front of the shock wave that passed through the window openings, the second point - the maximum value of the pressure in the flow wave $\Delta P_{z a t}^{\max }$. The pressure $\Delta P_{p r}$ is determined from the graph (Fig. 2) depending on $\Delta P_{F}$ and the perforation coefficient $\alpha$ equal to the ratio of the area of the holes to the area of the obstacle. The pressure $\Delta P_{z a t}^{\max }$ is determined taking into account the conditions that the leakage wave establishes an air flow of leakage, which continues until the pressure inside the building reaches the pressure in front of the hole $\Delta P_{z a t}^{\max }=\Delta P t_{\text {nar }}$. Practically $\Delta P_{z a t}^{\max } \approx \Delta P t_{\text {nar }}$. 


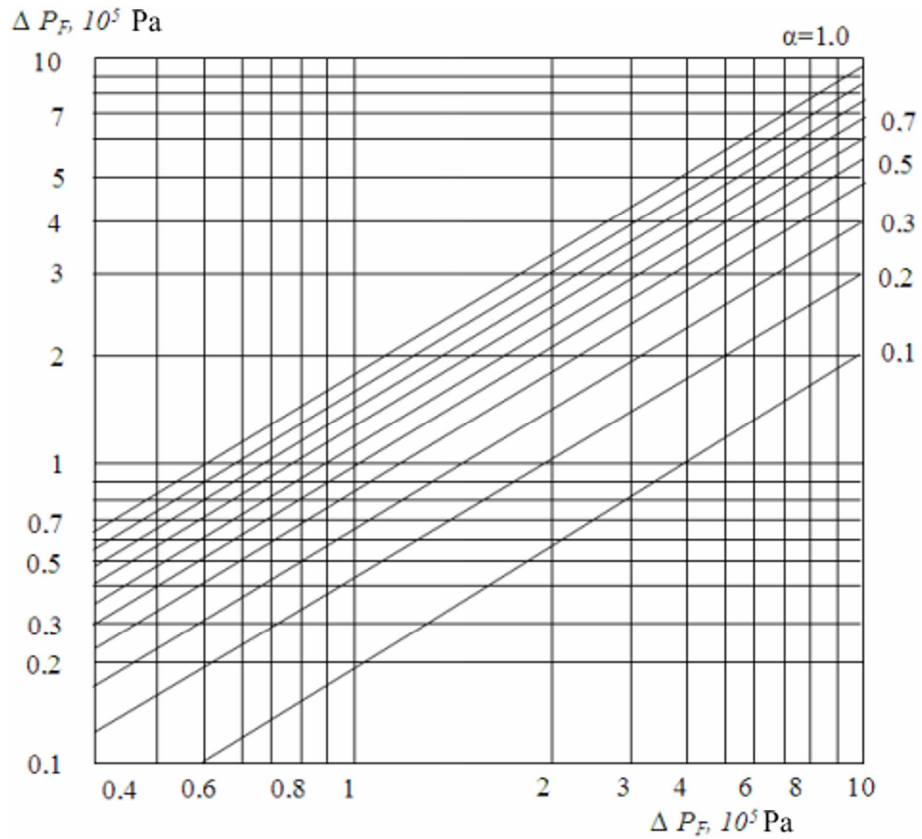

Fig. 2. The pressure depended $\Delta P_{p r}$ from parameters $\alpha$ and $\Delta P_{F}$

To determine the parameters of the wave that flows into the building, taking into account the destruction of the enclosing structures, you can use the following prerequisites: the time of destruction of the building is equal to the time of destruction of its front wall; deformation of the frame of the building during the destruction of the walls is not taken into account, the dynamic load is considered to be normally applied to the surface of the front wall; the load on the front wall (from pressure $\Delta P_{v i d}$ ) and its rear surface (from pressure $\left.\Delta P_{p r}\right)$ act simultaneously.

1. Determining the time of destruction of prefabricated buildings. The change in load $P(t)$ on the front wall width $b$ will be taken as the difference between the loads $P=P_{1}-P_{2}$ on the front and rear faces of the wall

$$
\begin{gathered}
P_{1}= \begin{cases}P_{o t r}\left(1-\frac{t}{\theta}\right), & 0<t \leq t_{o b t} \\
P_{o t r}\left[1-\frac{\left(t-t_{o b t}\right)}{\left(\tau_{e}-t_{o b t}\right)}\right], t_{o b t} \leq t<\tau_{e}\end{cases} \\
P_{2}= \begin{cases}P_{p r} \frac{\left(P_{z a t}^{\max }-P_{p r}\right) t}{t^{\text {nar }}}, & 0<t \leq t_{\text {nar }} \\
P_{z a t}^{\max }\left[1-\frac{\left(t-t_{\text {nar }}\right)}{\left(\tau_{e}-t_{\text {nar }}\right)}\right], & t_{\text {nar }} \leq t \leq \tau_{e},\end{cases}
\end{gathered}
$$


where $-P_{o t r}=\Delta P_{o t r}^{b}, P_{o b t}=\Delta P_{o t r}^{b}, P_{p r}=\Delta P_{p r}^{b}, \theta=2 t_{o b t}, \Delta P_{o t r}=\frac{\Delta P_{o t r}}{2}$.

There may be different relationships between moments of time $t_{\text {nar }}, t_{o b t}$ and time of destruction $t_{r a z}$. However, regardless of the order of alternation of these moments of time, the load will always have a linear shape, which leads to the same type of formulas in dynamic calculations. You only need to follow the necessary transitional conditions.

Thus, the first segment of the load over time can be represented as

$$
P(t)=P_{1}-P_{2}=P_{*}\left(1-\frac{t}{\tau_{*}}\right),
$$

where $P_{*}, \tau_{*}$ easy to express through load parameters $P_{1}, P_{2}$ and

$$
0<t \leq t_{\text {obt }} \leq t_{\text {nar }} \text { or } 0<t \leq t_{\text {nar }} \leq t_{\text {obt }}
$$

At $\alpha \rightarrow 1 \Delta P_{p r} \rightarrow \Delta P_{F}$, that is, at values $\alpha>0,5, \Delta P_{p r}=\Delta P_{F}$.

Considering also that $P_{z a t}^{\max } \approx \Delta P_{F}$, we get a stationary area of back pressure $P_{2}$ at $0<t<t_{\text {nar }}$. Since, $\tau_{*} \gg t_{\text {nar }}$, for the function $P(t)$ can accept (4) if

$$
\tau_{*}=\frac{P_{*} \theta}{\left(P_{o t r}-\left(P_{p r} \theta / t_{n a r}\right)\right)} .
$$

Schematize the panel with a single-span hinged beam as an elastic-plastic system with one degree of freedom. The termination of the flexible stage marked as $t_{2}$ is due to the armature breakdown resulting in rupture. Rupture time is $t_{r a z}=t_{1}+t_{2}$.

Let us write down the dependencies for a certain time $t_{r a z}$ is less or equals $t_{r a z} \leq t_{o b t}$. In the flexible stage, the $M$ resisting moment of spill beam 1 is:

$$
M(t)=\frac{1}{8} l P_{*} T_{(t)} .
$$

The dynamic function $T$ from the $T^{\prime \prime}+\omega^{2} f(t)$ equation is

$$
T(t)=T_{o} \cos \omega t+T_{o}^{\prime} \omega^{-1} \sin \omega t+\omega \int_{o}^{t} f(u) \sin \omega(t-u) d u,
$$

where $-T_{o}, T_{o}^{\prime}$ are the initial values of $T$ and $T^{\prime} ; \omega$ - natural frequency; $f$-dimentionless load, top dot indicates $t$ derivative.

Linear function $f=1-t / \tau_{*}$ where $T_{o}=T_{o}^{\prime}=0$ is

$$
T(t)=1-\frac{t}{\tau_{*}}-\cos \omega t+\frac{(\sin \omega t)}{\left(\omega \tau_{*}\right)} .
$$

Incorporating (9) into (7) we get $M\left(t_{1}\right)=M_{o}$ where $M_{o}$ is the boundary flexible moment, and then find the value of $t_{1}$.

Equation of motion panel in the plastic stage in continuation, what $M_{o}(t) \equiv$ const at $t>t_{1}$, has a pitchfork 


$$
m l^{3} \varphi^{\prime \prime}=3 P(t) l^{2} 24 M_{o},
$$

where $-P$ and $m$ - are the load and mass per unit of length; $\varphi-$ is the angular deflection of the beam as a system of two solid elements held together by a flexible hinge

After we accept the time recording starting at $t_{1}$ and introducing $\delta_{1}=1-t_{1} / \tau_{*}$ and integrating (4) into (10), we get

$$
\varphi(t)=\frac{3 P_{*}}{m l}\left(\frac{\delta_{1} t^{2}}{2}-\frac{t^{3}}{6 \tau_{*}}\right)-\frac{12 M_{o}}{m l^{3}} t^{2}+\varphi_{1} t+\varphi_{1} \equiv F(t),
$$

where $-\varphi$ is the rotational speed and rotational angle where $t=t^{1}-0$.

The speed of $\varphi_{1}\left(t_{1}+0\right)$ is calculated considering the change in the movement form of the beam suggesting constant motion. For the beam in question, the speed at the t moment of time increases by $23 \%$. The $\varphi_{1}$ angle is calculated using the following formula

$$
\varphi_{1}=\frac{51 M_{0}}{(24 B)}=\frac{2 y_{0}}{l},
$$

where $-B$ is bend firm of the beam's cross; $y_{o}$ is the flexible deflection.

The moment of time $t_{r a z}$ can be derived from (11) via the boundary value of $\varphi\left(t_{2}\right)=\varphi_{p r}^{*}$, corresponding to beam rupture.

The value of $\varphi_{p r}^{*}$ is determined via experiment and can be standardized by the number $\mathrm{n}$ of flexible deflections $\mathrm{y}_{\mathrm{o}}$ with the help of the ratio (12). Experiments with models building have shown 1:5 that, when loaded more than panels can hold, support mounts rupture after the armature. At the moment of concrete failure to the full height of the compressed zone, the deflection is about $1 / 15$ he span (the crack opening angle in beams with reinforcement of class A-III $\varphi_{p r}^{*}=2 \varphi_{p r}^{*} \cong 0,27 \mathrm{rad}$ ), and the ratio of the ultimate deflection to elastic.

After integrating $\varphi_{p r}^{*}$ or $\frac{2 \varphi_{p r}^{*}}{l}=\frac{28 y_{0}}{l}$ into (11), we can find the $t_{2}$ from $F\left(t_{2}\right)=\varphi_{p r}$ or $F\left(t_{2}\right)=\frac{28 y_{0}}{l}=\frac{35 M_{0} l}{12 B}$.

Similarly, we can derive the variable dependencies with other ratios of time variables: $t_{r a z}, t_{o b t}, t_{\text {nar }}$.

In order to test the calculated dependencies, experiments were conducted involving sir shock wave rupture front and back walls of a building model scale 1:5 with U-sectioned frame and enclosing structures from armored concrete panels size $0,096 \mathrm{~m}^{2}$. Outside dimensions of the model: height 1,7 , width 1,32 , length $4 \mathrm{~m}$. 
Panels were armored with symmetric welded steel frames class A-III with $8 \mathrm{~mm}$ in diameter (relative deformation in case of rupture: $\approx 14 \%$ ). Armoring coefficient was 0,0027 . Concrete class B50. Rupture time $0,2 \mathrm{sec}$.

Wall rupture time (Table 1) made of armored concrete panels $12 \mathrm{~cm}$ thick and $1800 \mathrm{~kg} / \mathrm{m}^{3}$ dense was calculated based on rupture time of wire indicators. The results of experiments and calculations are fairly similar. Figure 3 shows calculation results for the dependency of wall rupture time on pressure $\Delta P_{F}$ and the $\alpha$ coefficient. Works for natural panels with the following specifications: height $6 \mathrm{~m}$, width $1,2 \mathrm{~m}$, thickness $24 \mathrm{~cm}$. Armoring coefficient 0,0015 , armature class A-III, pored concrete class B25 density $750 \mathrm{~kg} / \mathrm{m}^{3}$.

Table 1

Experimental and calculated values of wall panel rupture time

\begin{tabular}{|c|c|c|c|}
\hline \multirow{2}{*}{$\Delta P_{F}, 10^{5} \mathrm{~Pa}$} & \multicolumn{2}{|c|}{ Rupture time, mil sec } & \multirow{2}{*}{ Exp / Cal } \\
\cline { 2 - 3 } & experiment & calculation & \\
\hline 0,63 & 30 & 28 & 1,07 \\
1,13 & 19 & 25 & 0,76 \\
1,45 & 17 & 19 & 0,89 \\
\hline
\end{tabular}

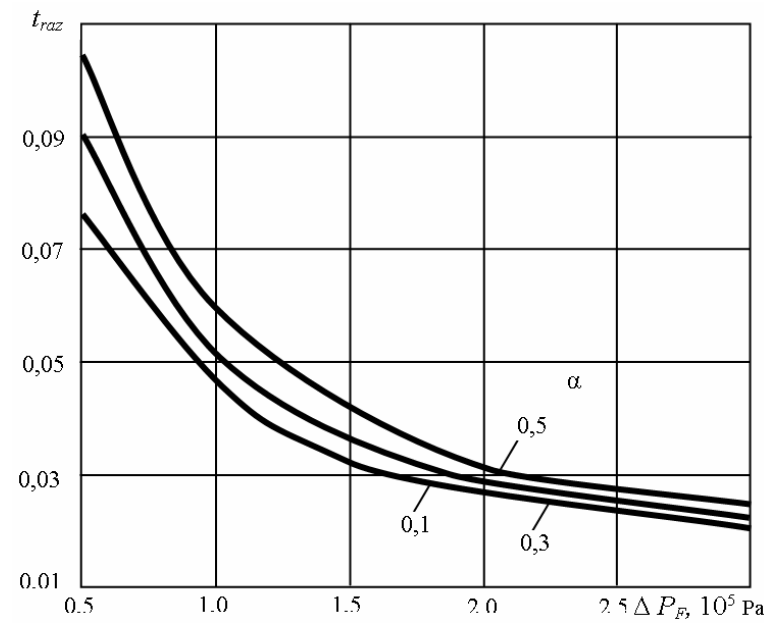

Fig. 3. Dependency of concrete-paneled building wall rupture time on $\Delta P_{F}$

pressure and $\alpha$ coefficient. For $1100 \mathrm{~kg} / \mathrm{m}^{3}$ panels, $t_{r a z}$ time should be multiplied by 1,2

Calculation analysis shows that panel rupture time when $\alpha=0,3$ (penetration 30\%), depending on $\Delta P_{F}$ varies between 20 to $100 \mathrm{Msec}$, while, if pressure increases, the penetration impacts on $t_{r a z}$ decreases. Rupture time calculations for panels $1100 \mathrm{~kg} / \mathrm{m}^{3}$ have shown that, if $t_{r a z}$ changes in a similar way, its value will increase by approximately $20 \%$. 


\section{Parameters of the wave flowing into the panel and brick buildings} with openings (holes). Estimated loads on the elements of buildings, structures are determined taking into account the change in pressure inside the buildings [4]. To determine the main parameters that characterize the change in pressure inside the building, taking into account the destruction, experiments were conducted on a model of an industrial building on a scale of 1: 5. The walls of the model were obstacles with openings typical of buildings. Under the influence of an air shock wave, the front and rear walls collapsed. The change in pressure inside the model was recorded by membrane sensors. A typical oscillogram of pressures in the flow wave is shown in Figs. 4a, 4b.

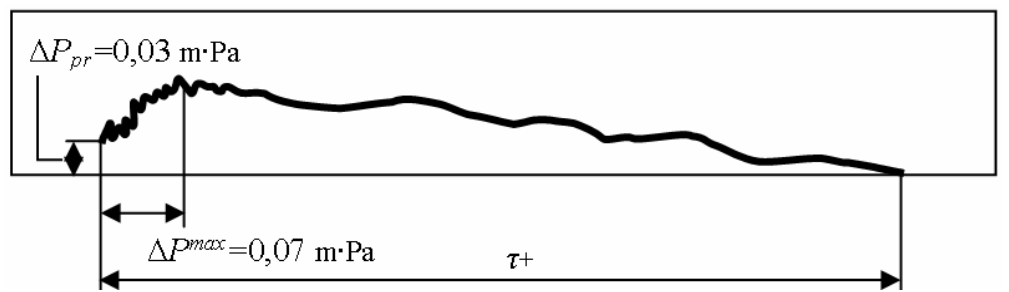

(a)

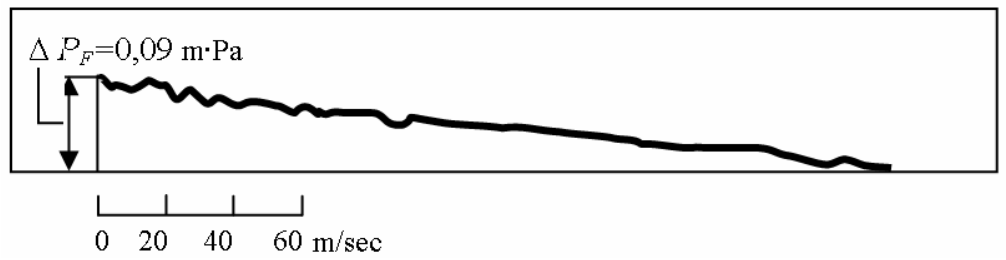

(b)

Fig. 4. Pressure change over time inside a building/construction model with openings (a) and outside (b)

Figure 4 shows that at the initial moment the pressure increases by a jump, then to the maximum value the pressure changes smoothly. Some pressure fluctuations near the midline are caused by waves repeatedly reflected from walls and debris. The change in pressure in the flow wave with sufficient accuracy for practice can be approximated in the form of a graph shown in Figure 1. Assume the maximum pressure $\Delta P_{z a t}^{\max }$ is approximately equal to the pressure $\Delta P_{F}$.

It is defined that, if $t_{r a z}<t_{z a t}$, the time of increase $t_{r a z}$ inside equals wall rupture time. If the wave penetration ends by the time the wall collapses, then the time $t_{r a z} \approx t_{z a t}$.

The $t_{z a t}$ is defined via graph shown in Figure 5, calculated based on statistical analysis of wave penetration experiment results for buildings for which the ratio of the area of the openings to the internal volume $V$ more 
$0,01 \mathrm{~m}^{-1}$. Experiments prove that compression phase for penetrating waves equals $\tau_{*}$ compression phase for shock wave.

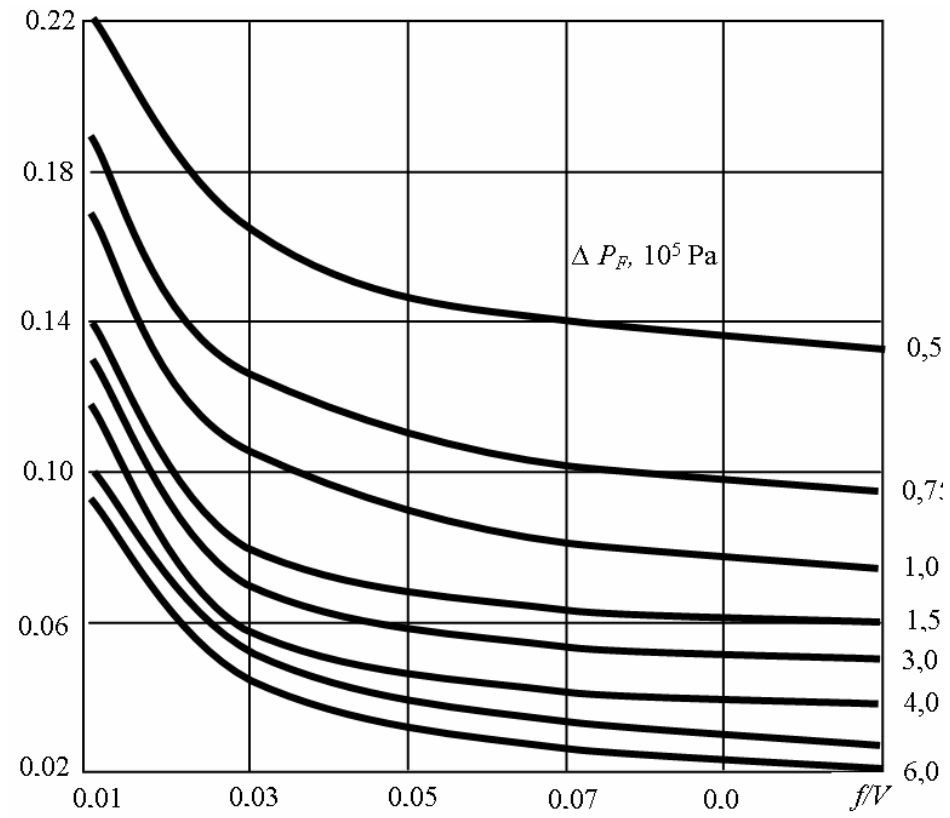

Fig. 5. The dependence of the time of penetration of the wave into the first floors of the building, structure on the ratio and pressure

The results of experiments and their comparison with the calculation are shown in table 2. Comparison of calculated and experimental data indicates their sufficient convergence.

Table 2

The value of the parameters of the wave flowing into the brick buildings

\begin{tabular}{|r|r|c|c|c|c|c|c|c|}
\hline \multirow{2}{*}{$\begin{array}{r}\Delta P_{F}, \\
15^{5} \mathrm{~Pa}\end{array}$} & \multirow{2}{*}{$f / V}$, & \multicolumn{2}{|c|}{$\begin{array}{c}\text { Wall } \alpha \\
\text { coefficient }\end{array}$} & $\begin{array}{c}\Delta P_{z a t}^{\max }, 10^{5} \mathrm{~Pa} \\
\end{array}$ & $1 / \mathrm{m}$ & \multicolumn{2}{|c|}{$t_{\text {nar }}, \mathrm{m} / \mathrm{sec}$} & \multicolumn{2}{|c|}{$\Delta P_{p r}, 10^{5} \mathrm{~Pa}$} \\
\cline { 3 - 9 } & front & rear & Exper. & Exper. & Calc. & Exper. & Calc. \\
\hline 0,60 & 0,055 & 0,2 & 0 & 0,46 & 18 & 21 & 0,22 & 0.23 \\
0,93 & 0,055 & 0,2 & 0 & 0,66 & 16 & 15 & 0,27 & 0,34 \\
0,74 & 1,109 & 0,4 & 0 & 0,73 & 15 & 17 & 0,39 & 0,43 \\
0,90 & 0,109 & 0,2 & 0,2 & 0,70 & 16 & 15,7 & 0,34 & 0,33 \\
0,77 & 0,109 & 0,4 & 0,4 & 0,63 & 15 & 14 & 0,40 & 0,46 \\
1,06 & 0,218 & 0,4 & 0 & 0,85 & 14 & 14 & 0,61 & 0,60 \\
\hline
\end{tabular}

Conclusion. Studying the parameter of an explosion shock wave that penetrates buildings have shown that building-mount construction loads 
depend on the parameters of the wave that penetrates openings of a building or construction.

In order to determine the parameters of a wave that penetrates a building, considering that its enclosing structures have been ruptured, we accepted the following pre-conditions: building rupture time equals the rupture time of its front wall; building frame deformation was not considered, dynamic load was considered standardly applied to the front wall surface; front wall load (from $\Delta P_{o t r}$ ) and its rear surface (from $\Delta P_{p r}$ ) are considered simultaneously applied.

Determination of the time of destruction of panel structures on building models on a scale of 1:5 showed that under loads that are an order of magnitude or more exceeding the load-bearing capacity of the panels, the support fasteners are destroyed after the break of the reinforcement. At the moment of rupture of the concrete, at the full height of the compressed zone, the deflection is about $1 / 15$ the span, the crack opening angle $\varphi_{p r}^{*}=2 \varphi_{p r}^{*} \cong 0,27 \mathrm{rad}$. Calculation analysis shows that panel rupture time for $\alpha=0,3$ (notch $30 \%$ ), depending on $\Delta P_{F}$, varies between 20 to $100 \mathrm{Msec}$, while pressure increase causes opening impact decrease for $t_{r a z}$. Rupture time calculations for $1100 \mathrm{~kg} / \mathrm{m} 3$ panels have shown that, if the value of $t_{r a z}$ changes under similar pattern, its value will increase by approximately $20 \%$.

Under air shock wave impact, the front and rear walls of the construction were ruptured. During the parameter calculation for waves penetrating a building through an opening, experimental and calculated data showed an acceptable level of concordance.

\section{REFERENCES}

1. Vasiychuk V.O. Osnovy tsyvilnoho zakhystu (Fundamentals of civil protection): Navch. posibnyk / V.O. Vasiychuk, V.Ye Honcharuk, S.I. Kachan, S.M. Mokhnyak - Lviv: Vydavnytstvo Natsionalnoho universytetu "Lvivska politekhnika", 2010.417s. (in Ukrainian)

2. Bykova O.V. Boliyev O.V., Derevynskyy D.M., Yeliseyev V.N., Myronets S.M., Osypenko S.I., Piven YU.O. ta insh. Osnovy tsyvilnoho zakhystu (Fundamentals of civil protection): Navch. posibnyk K: 2008.- 223 s. (in Ukrainian)

3. Vasylchenko O.V. Budivelni konstruktsiyi ta yikh povedinka $\mathrm{v}$ umovakh nadzvychaynykh sytuatsiy (Building structures and their behavior in emergency situations): Navchalnyy posibnyk / O.V. Vasylchenko, YU.V. Kvitkovskyy, O.V. Myrhorod, O.A. Stelmakh. - Kharkiv: KHNADU, 2015. - 488s. (in Ukrainian)

4. Mkrtychev O.V. Raschet konstruktsiy zhelezobetonnogo zdaniya na vzryvnyye nagruzki $\mathrm{v}$ nelineynoy dinamicheskoy postanovke (Analysis of structures of a reinforced concrete building for explosive loads in a nonlinear dynamic setting)/ O.V. Mkrtychev, V.B. Dorozhinskiy, O.V. Lazarev // Vestnik MGSU. - 2011. - №4. - S. 243-247. (in Russian)

5. RD 03-409-01. Metodika otsenki posledstviy avariynykh vzryvov toplivno-vozdushnykh smesey (Methodology for assessing the consequences of emergency explosions of fuel-air mixtures). - M.: ZAO NTTS PB, 2014. - 38 s. (in Russian)

6. Chub I.A. Prohnozuvannya naslidkiv nadzvychaynoyi sytuatsiyi $\mathrm{z}$ vybukhom khmary hazopovitryanoyi sumishi (Forecasting the consequences of an emergency situation with the explosion of a cloud of gas-air mixture) / I.A. Chub, V.V. Matukhno // Problemy nadzvychaynykh sytuatsiy. - 2016. - Vyp. 23. - S.186-191. (in Ukrainian) 
7. Rybakov A.V. Raschot ustoychivosti konstruktsiy zdaniy $\mathrm{k}$ udarno-volnovym nagruzkam (Calculation of the resistance of building structures to shock-wave loads)// Nauchnyye i obrazovatel'nyye problemy grazhdanskoy zashchity, № 4, 2013. S. 23-27. (in Russian)

8. Kobylkin I.F. Udarnyye i detonatsionnyye volny: Metody issledovaniya (Shock and Detonation Waves: Research Methods )/ [I.F. Kobylkin, V.V. Selivanov, V.S. Solov'yev, N.N. Sysoyev].M.: Fizmatlit, 2004. - 375s. (in Russian)

9. Kvitkovskyy Yu.V. Vyznachennya parametriv udarnoyi khvyli, shcho utvoryuyetsya pid chas vybukhu hazopovitryanoyi sumishi (Determination of the parameters of the shock wave generated during the explosion of the gas-air mixture)/ Kvitkovskyy YU.V, Prokhach E.YU.// Zbirka naukovykh prats UTSZU. - №4, 2006. - S.120-124. (in Ukrainian)

10. Mukhin V.I., Rybakov A.V., Vil'danov R.R. O raschetnoy modeli otsenki porazhayushchego vozdeystviya vozdushnoy udarnoy volny ot obychnikh sredstv porazheniya (On a computational model for assessing the damaging effect of an air shock wave from conventional weapons)// Izvestiya Instituta inzhenernoy fiziki. 2017. №1, s. 58-63. (in Russian)

11. Nabiullin M.I. Matematicheskaya model' rascheta amplitudy izbytochnogo davleniya na fronte vozdushnoy udarnoy volny (Mathematical model for calculating the amplitude of excess pressure at the front of an air shock wave) / M.I. Nabiullin, A.V. Guseva, D. Yu. Verin, S.A. Vilokhin // Vestnik tekhnologicheskogo universiteta. 2017. T.20, №3 - S. 141-144. (in Russian)

Стаття надійшла 15.10.2020

Шишанов М.О., Малюга В.Г., Коваль В.В., Мірненко В.І., Філь В.М., Ганненко С.О., Дужий Р.В.

\section{ВПЛИВ ПОВІТРЯНОЇ УДАРНОЇ ХВИЛІ НА БУДІВЛІ І СПОРУДИ}

Руйнування будівель та споруд відбувається внаслідок стихійних лих, аварій різного характеру та терористичних актів, що в багатьох випадках супроводжуються вибухами. В ході ведення збройних конфліктів руйнування будівель, споруд відбувається у результаті наскрізного пробивання засобами ураження перекриття або стін 3 подальшою детонацією боєприпасу всередині споруди, виникненням руйнівної дії кінетичної енергії продуктів вибуху та ударної хвилі.

Дія ударної хвилі на будівлі, споруди характеризується складним комплексом навантажень: надлишковим тиском, тиском відбивання, тиском швидкісного напору, тиском затікання, навантаженням від сейсмічних хвиль.

Забезпечення збереження й відновлення будівель і споруд включає заходи оцінки можливих ступенів руйнування будівель $\mathrm{i}$ споруд. Тому у сучасних умовах проектування будівель, споруд та їх елементів не можливе без урахування динамічних впливів. При проектуванні та будуванні будівель, споруд завжди потрібно враховувати стійкість елементів конструкцій до дії вражаючих факторів, як вибуху в цілому так і ударної хвилі вибуху зокрема, що допоможе уникнути майбутніх можливих людських втрат.

Враховуючи це в статті розглянуто загальну характеристику процесів взаємодії повітряної ударної хвилі з будівлею, метод розрахунку часу руйнування панельних споруд та основні параметри повітряної ударної хвилі, яка затікає у результаті вибуху в будівлі, споруди з віконними, дверними прорізами, які виникли в наслідок руйнування конструкцій перекриття або стін.

Дослідження показують, що навантаження на конструкції залежать від параметрів хвилі, яка затікає через прорізи в споруди, які утворюються при руйнуванні стін будівлі, зіставлення розрахункових і експериментальних даних свідчить про їх достатню збіжність.

Ключові слова: повітряна ударна хвиля, динамічне навантаження, тиск відбиття, тиск прориву, тиск наростання, тиск обтікання, час руйнування. 
Shyshanov M.O., Maliuha V.G., Koval V.V., Mirnenko V.I., Fil V.M., Hannenko S.O., Duzhyi R.V. INFLUENCE OF AIR SHOCK WANE ON BUILDINGS AND STRUCTURES

The destruction of buildings and structures occurs as a result of natural disasters, accidents, or terorist attactacts which in many cases are accompanied by explosions.

The action of an air shock wave on a building is characterized by a complex set of loads: excess pressure, reflection pressure, velocity pressure, leakage pressure, load from seismic waves.

Ensuring the preservation and restoration of buildings and structures includes measures to assess the possible degree of destruction of buildings and structures. Therefore, in modern conditions, the design of buildings, structures and their elements is not possible without taking into account the dynamic effects. When designing and constructing buildings and structures, it is always necessary to take into account the resistance of structural elements to the action of damaging factors, both the explosion in general and the shock wave of the explosion in particular, which will help avoid future possible human losses.

Therefore, the article considers the general characteristics of the processes of interaction of the air shock wave with the building, the method of calculating the time of destruction of prefabricated buildings and the main parameters of the air shock wave which flows as a result of an explosion in a building, structure with windows, doorways and openings, which arose as a result of the destruction of floor structures or walls.

Studies have shown that the load on the structure depends on the parameters of the wave that flows through the holes in the buildings and through the holes formed by the destruction of the walls of the building, the comparison of calculated and experimental data indicates their sufficient convergence.

Key words: air shock wave, dynamic loading, reflection pressure, breakthrough pressure, growth pressure, flow pressure, fracture time.

УДК 623.1/.7:007.52 (477)

Шишанов М.О., Малюга В.Г., Коваль В.В., Мірненко В.І., Філь В.М., Ганненко С.О., Дужий Р. В. Вплив повітряної ударної хвилі на будівлі, споруди // Опір матеріалів і теорія споруд: наук.-тех. збірн. - К.: КНУБА, 2020. - Вип. 105. - С. 179-191.

В статті розглянуто загальну характеристику процесів взаємодії повітряної ударної хвилі з будівлею, метод розрахунку часу руйнування панельних споруд та основні параметри повітряної ударної хвилі.

Табл. 2. Рис. 5. Бібліогр. 11 назв.

UDC 623.1/.7:007.52 (477)

Shyshanov M.O., Maliuha V.G., Koval V.V., Mirnenko V.I., Fil V.M., Hannenko S.O., Duzhyi R.V.

Influence of air shock wane on buildings and structures // Strength of Materials and Theory of Structures: Scientific-and-technical collected articles - Kyiv: KNUBA, 2020. - Issue 105. P. 179-191.

Article considers the general characteristics of the processes of interaction of the air shock wave with the building, the method of calculating the time of destruction of prefabricated buildings and the main parameters of the air shock wave.

Tabl. 2. Fig. 5. Ref. 11.

Автор (вчена ступень, вчене звання, посада): доктор технічних наук, професор, провідний науковий співробітник Центрального науково-дослідного інститут озброєння та військової техніки Збройних Сил України, ШИШАНОВ Михайло Олексійович

Адреса робоча: 03049, м. Київ, Повітрофлотський проспект, 28, Центральний науководослідний інститут озброєння та військової техніки Збройних Сил України.

Робочий тел.: +38 044 520-12-84.

Мобільний тел.: +38(067) 538-43-18

ORCID ID: http://orcid.org/0000-0002-7121-3666 
Автор (вчена ступень, вчене звання, посада): доктор військових наук, старший науковий співробітник, начальник кафедри тактики ЗРВ Харківського національного університету Повітряних Сил імені Івана Кожедуба, МАЛЮГА Володимир Генадійович

Адреса робоча: 61045 , м. Харків, вулиця Клочківська, 228, Харківський національний університет Повітряних Сил імені Івана Кожедуба.

Мобільний тел.: +38(099) 770-65-60,

E-mail: maluga_v@i.ua

ORCID ID: http://orcid.org/0000-0001-6227-1269

Автор (вчена ступень, вчене звання, посада): кандидат військових наук, старший науковий співробітник, начальник воєнно-наукового управління Генерального штабу Збройних Сил України, КОВАЛЬ Володимир Валерійович

Адреса робоча: 03049, м. Київ, Повітрофлотський проспект, 28, Воєнно-наукове управління Генерального штабу Збройних Сил України

Робочий тел.: +38 044 234-32-39

Мобільний тел.: +38(096) 103-26-01

E-mail: kovalvvol@ukr.net

ORCID ID: http://orcid.org/0000-0002-6209-6779

Автор (вчена ступень, вчене звання, посада): доктор технічних наук, професор, директор департаменту освіти і науки Міністерства оборони України, МІРНЕНКО Володимир Іванович

Адреса робоча: 03049 , м. Київ, Повітрофлотський проспект, 28, Департамент освіти і науки Міністерства оборони України.

Робочий тел.: +38 044 271-06-97, факс +38 044 271-06-9703680.

Мобільний тел.: +38(067) 445-79-60,

ORCID ID: https://orcid.org/0000-0002-7484-1035

Автор (вчена ступень, вчене звання, посада): кандидат технічних наук, доцент, викладач кафедри оперативного та бойового забезпечення Національного університету оборони України імені Івана Черняховського, ФІЛЬ Віктор Миколайович

Адреса робоча: 03049 , м. Київ, Повітрофлотський проспект, 28, Національний університет оборони України імені Івана Черняховського.

Робочий тел.: +38 044 271-08-68, факс +38 044 271-06-9703680.

Мобільний тел.: +38(097) 908-71-78,

E-mail: victorof3@gmail.com

ORCID ID: https://orcid.org/0000-0003-0013-874X

Автор (вчена ступень, вчене звання, посада): старший викладач кафедри зв'язку та автоматизованих систем управління Національного університету оборони України імені Івана Черняховського, ГАННЕНКО Світлана Олександрівна

Адреса робоча: 03049, м. Київ, Повітрофлотський проспект, 28, Національний університет оборони України імені Івана Черняховського

Робочий тел.: +38 044 271-08-68, факс +38 044 271-06-97 03680

Мобільний тел.: +38(067) 769-85-02

E-mail: zima_sveta@ukr.net

ORCID ID: $\bar{h}$ ttps://orcid.org/0000-0002-8285-1145

Автор (вчена ступень, вчене звання, посада): заступник начальника центру - начальник відділу впровадження інноваційних технологій та технічного супроводження навчального процесу навчально-наукового центру підготовки офіцерів для багатонаціональних штабів Національного університету оборони України імені Івана Черняховського, ДУЖИЙ Роман Володимирович

Адреса робоча:03049, м. Київ, Повітрофлотський проспект, 28, Національний університет оборони України імені Івана Черняховського

Робочий тел.: +38 044 271-09-12, факс +38 044 271-06-97 03680

Мобільний тел.: +38(050) 606-81-66

E-mail: romeojuliet@ukr.net

ORCID ID: $\underline{\text { https://orcid.org/0000-0002-8064-1312 }}$ 